\title{
Effects of Antarctic Krill Products on Feed Intake, Growth Performance, Fillet Quality, and Health in Salmonids
}

\author{
Kiranpreet Kaur $\mathbb{D}^{1}{ }^{1}$ Trond M. Kortner, ${ }^{2}$ Tibiabin Benitez-Santana, ${ }^{1}$ and Lena Burri ${ }^{1}$ \\ ${ }^{1}$ Aker BioMarine Antarctic AS, Lysaker, Norway \\ ${ }^{2}$ Faculty of Veterinary Medicine Norwegian University of Life Sciences, Oslo, Norway
}

Correspondence should be addressed to Kiranpreet Kaur; kiranpreet.kaur@akerbiomarine.com

Received 25 October 2021; Accepted 27 November 2021; Published 31 January 2022

Academic Editor: Mansour Torfi Mozanzadeh

Copyright (c) 2022 Kiranpreet Kaur et al. This is an open access article distributed under the Creative Commons Attribution License, which permits unrestricted use, distribution, and reproduction in any medium, provided the original work is properly cited.

\begin{abstract}
The interest for krill-based ingredients for aquaculture feed applications has increased steadily in recent years. For decades, there has been a heavy reliance on the limited sources of fishmeal and fish oil in the salmonid aquaculture industry. Further growth in farming of carnivorous fish is dependent on new feed resources becoming available. The only unexploited marine resources of significant biomass are found at lower trophic levels, of which the Antarctic krill (Euphausia superba) has a high potential. Apart from being the biggest single species biomass, Antarctic krill is also rich in nutrients, such as omega-3 polyunsaturated fatty acids, phospholipids, astaxanthin, vitamins, and minerals. This makes Antarctic krill a high-quality source of healthbeneficial lipids and proteins. The present article provides an overview on the documented benefits of feeding salmonids (Atlantic salmon (Salmo salar) and rainbow trout (Oncorhynchus mykiss)) with krill products (krill meal, krill oil, and krill hydrolysate), focusing on growth performance (feed intake, growth rate, and feed conversion), fillet quality, slaughter yield, and health benefits in terms of reducing fat accumulation in liver and intestinal tissues. Besides, the article discusses possible future studies, to widen the knowledge on krill benefits in salmonids and to unravel the underlying mechanisms.
\end{abstract}

\section{What Is Krill}

Krill constitute a group of marine, pelagic crustaceans. They belong to the order Euphausiacea, in which about 85 species have been recorded [1]. Antarctic krill (Euphausia superba) is one of the most abundant species on earth, with an estimated biomass of around 500 million tons [2]. They are shrimp-like in appearance, with an average body length of only $5 \mathrm{~cm}$, with big black eyes and a reddish, semitransparent shell. Krill plays a key role in the marine food chain in the Antarctic Ocean, and hence, krill harvesting is highly regulated by the Commission for the Conservation of Antarctic Marine Resources (CCAMLR) [3]. Only a certain section, i.e., area encompassing the Antarctic Peninsula, called area 48 , is allowed for commercial krill harvesting with an annual sustainable harvesting quota, limited to $1 \%$ of the total estimated biomass in this area. However, the commercial harvesting is even lower than the quota permitted, representing less than $0.5 \%$ of the unexploited biomass. These strict regulations of Antarctic krill harvesting have led to an increase in its biomass over the years, from 60.3 million tons measured in 2000 to 62.6 million in 2018/19 according to the findings from CCAMLR [4]. Besides Antarctic krill, Euphausia pacifica is the commercially harvested krill species, from the Pacific Ocean (off the coast of Japan and off the coast of British Columbia, Canada). The small-scale harvesting also occurs on other North Pacific krill species such as Euphausia nana and Thysanoessa inermis, from the Japanese coast, and Thysanoessa raschii and Meganyctiphanes norvegica, in the Gulf of St. Lawrence, Canada, respectively [5].

Considerable innovation has been displayed over the years to improve the harvesting and processing technology, as well as to produce different Antarctic krill products such as freeze-dried krill concentrate, krill hydrolysate, and protein concentrate [6]. During the early stages of product development from Antarctic krill, the primary focus was human consumption. The possibility for using krill as a feed 
ingredient for fish started in the late 1970s and early 1980s, which was nicely reviewed by [7] in an attempt to explore krill's nutrient values, such as high palatability, and its ability to enhance feed intake and increase growth performance in salmonids. Later, the expansion of aquaculture led to a steady increase in the use of krill in feeds, as a replacement of limited marine resources such as fish meal (FM) and fish oil (FO). In addition, the usage of these limited resources for direct human consumption, as well as for livestock, and their fluctuating prices serve as the main driving forces for the aquaculture industry to look for more sustainable, alternative marine ingredients. The sustainability and the nutritional values (phospholipids, omega-3 fatty acids, highquality marine protein, and astaxanthin-serving the dual role of natural antioxidant and a carotenoid source) of krill meal (KM) along with high palatability were some of the attractive features for both the farmers and aquaculture industry to test the inclusion of KM in salmonid feeds. The interest in KM has steadily increased over the years, with the number of studies increasing accordingly in the scientific literature, covering aspects to test the effects on growth performance, fillet quality, robustness in terms of organ health, and ability to cope with stress such as seawater transfer stress (Table 1). The studies conducted are mainly focused on the seawater phase, which is the most challenging phase in the production cycle of salmonids, covering the stages from seawater transfer and grower to slaughter phases. This review is aimed at providing an updated knowledge on the usage of krill in salmonid aquaculture diets (Table 1, Figure 1).

\section{Nutrient Composition of Different Krill Products}

Several products that are produced from Antarctic krill can be used in aquaculture feed formulations. KM is prepared from an extract of ground whole Antarctic krill that is cooked and dried, resulting in a brownish-orange powder containing around $60 \%$ protein with a nutritionally wellbalanced amino acid profile (Table 2).

$\mathrm{KM}$ is a sustainable source of protein, $\mathrm{n}-3$ phospholipids $(\mathrm{PL})$, feed attractants, and astaxanthin [8]. It has a proximate composition that is similar to FM with an almost identical amino acid profile. The lipid fraction of KM contains a high proportion of polar lipids, as well as a high content of polyunsaturated fatty acids (PUFAs), sterols (mainly cholesterol), and astaxanthin esters [9]. The combination of feed attractants and nutrients explains the growth-enhancing effects of KM.

Krill oil (KO) is extracted from KM and contains only the lipid fraction. It is rich in omega-3 PL, choline, and astaxanthin. Phosphatidylcholine (PC) is the main PL $(>80 \%)$ in $\mathrm{KO}$.

Krill hydrolysate $(\mathrm{KH})$ is prepared from an aqueous extract of KM that is cooked and cooled, followed by enzymatic hydrolysis. The water-soluble protein fraction is then extracted and concentrated after removing the solids and fat. KH contains high levels of free amino acids, such as ala- nine, proline, arginine, glutamine, leucine, and glycine, known to have an appetite regulative function in fish [10].

\section{Effects of Krill on Feed Intake and Growth Performance}

3.1. Oncorhynchus mykiss (Rainbow Trout). KM has been the most commonly used krill product in aquaculture industry for various fish species (marine, freshwater, and salmonids). A decent documentation on the effects of partial substitution of FM with KM (7-30\% of the diet) on growth and performance in salmonids is summarized in Table 1.

Early studies were often performed on rainbow trout as a model fish. Some of these studies showed that KM could partially replace FM, and that the partial replacement led to increased growth $[11,12]$. However, few studies found no effect or negative effects on growth $[13,14]$. These differences might be due to the variations in the experimental set up, feed compositions, developmental stage of rainbow trout, length of the feeding trial, water temperature, etc. as shown in the studies by Wei et al. [15] and Yoshitomi et al. [16], which are described in more detail in the following paragraphs. The effect of full FM replacement was somewhat contradictory, as some studies demonstrated that KM was fully interchangeable with FM $[17,18]$, while other studies showed reduced growth $[13,14]$. These early studies with very high KM inclusion levels were, however, not followed up, due to two potential reasons: partly because of $\mathrm{KM}$ at very high inclusion levels is too expensive to compete with the other, cheaper marine lipid and protein sources and partly because it was noted that the high fluoride content in krill could influence the suitability of the fish produced for human consumption [19]. The latter problem was, however, resolved, when it was shown that fluoride was primarily deposited in nonedible parts of the fish such as bone and scales [20]. For example, a study that has shown benefits with a $60 \% \mathrm{KM}$ inclusion observed an increased body weight $(450 \mathrm{~g})$ and size of rainbow trout, during a feeding period of 60 days, when compared to the $34 \%$ FM control group. Both the FM and KM diets were isonitrogenous. However, there were variations in the fatty acid profile of the two diets, with higher total n-3 PUFA in KM (18.0\% of total fatty acid) in comparison to FM (13.17\% of total fatty acid). It was observed that the KM diet increased the body weight and size and decreased the perivisceral fat and visceral weight indices. Besides, the KM diet provided a high-quality product from the nutritional point of view because it improved the fatty acid profile, with more n-3 fatty acids and less n6 fatty acids [21].

Interestingly, in a recent study on rainbow trout (102 g) in seawater, it was observed that high inclusion levels of KM $(15,30,60$, and $100 \%)$ as a FM replacement significantly increased the growth (final body weight and specific growth rate (SGR)) and feed intake after 8 weeks of feeding [15]. These results were in contrast to a study by Yoshitomi et al. [16], where partial replacement of FM with 7 and $15 \% \mathrm{KM}$ did not affect the growth performance, whereas $30 \% \mathrm{KM}$ led to reduced growth in comparison to the FM control [16]. The differences in growth performance results 
TABle 1: Overview of studies showing effects of krill on salmonid performance.

\begin{tabular}{|c|c|c|c|c|}
\hline Study & Initial weight & Diets & Duration & Main krill effects \\
\hline $\begin{array}{l}\text { Julshamn, Malde, } \\
\text { Bjorvatn, \& Krogedal, } \\
\text { [25] }\end{array}$ & $\begin{array}{l}410 \mathrm{~g} \\
\text { Atlantic } \\
\text { salmon }\end{array}$ & $0,10,20$, and $30 \% \mathrm{KM}$ & 84 days & $\begin{array}{l}\text { High tolerance to dietary fluoride with } \\
\qquad 350 \mathrm{mg} / \mathrm{kg} \text { diet } \mathrm{KM}\end{array}$ \\
\hline Ringø et al. [93] & $\begin{array}{l}105 \mathrm{~g} \\
\text { Atlantic } \\
\text { salmon }\end{array}$ & $\begin{array}{c}58.9 \% \mathrm{FM} \\
32 \% \mathrm{FM}+32 \% \mathrm{KM}\end{array}$ & 46 days & $\begin{array}{c}\uparrow \text { Aerobic and facultative aerobic bacteria } \\
\text { colonizing the hindgut } \\
\text { Dietary KM affected the adherent } \\
\text { hindgut microbiota }\end{array}$ \\
\hline Moren et al. [106] & $\begin{array}{l}412 \mathrm{~g} \\
\text { Atlantic } \\
\text { salmon }\end{array}$ & $0,28.1,30.3$, and $34.8 \% \mathrm{KM}$ & 100 days & $\begin{array}{l}\uparrow \text { Specific growth rate } \\
\uparrow \text { Copper }\end{array}$ \\
\hline Olsen et al. [26] & $\begin{array}{l}500 \mathrm{~g} \\
\text { Atlantic } \\
\text { salmon }\end{array}$ & $\begin{array}{c}0 \% \mathrm{KM}+60 \% \mathrm{FM} \\
13.5 \% \mathrm{KM}+48 \% \mathrm{FM} \\
27 \% \mathrm{KM}+36 \% \mathrm{FM} \\
40 \% \mathrm{KM}+24 \% \mathrm{FM} \\
54 \% \mathrm{KM}+12 \% \mathrm{FM} \\
68 \% \mathrm{KM}+0 \% \mathrm{FM}\end{array}$ & 140 days & $\begin{array}{l}\uparrow \text { Growth performance } \\
\uparrow \text { Feed conversion rate }\end{array}$ \\
\hline $\begin{array}{l}\text { Yoshitomi, Aoki, } \\
\text { Oshima, \& Hata, [16] }\end{array}$ & $\begin{array}{l}5.5 \mathrm{~g} \text { rainbow } \\
\text { trout }\end{array}$ & $\begin{array}{l}0 \% \mathrm{KM} \\
7 \% \mathrm{KM} \\
15 \% \mathrm{KM} \\
30 \% \mathrm{KM}\end{array}$ & 92 days & $\begin{array}{c}\text { 30\% KM: } \\
\downarrow \text { Growth } \\
\downarrow \text { Feed intake } \\
\downarrow \text { Specific growth rate }\end{array}$ \\
\hline $\begin{array}{l}\text { Suontama, Kiessling, } \\
\text { Melle, Waagb } \varnothing, \& \\
\text { Olsen, [27] }\end{array}$ & $\begin{array}{l}412 \mathrm{~g} \\
\text { Atlantic } \\
\text { salmon }\end{array}$ & $\begin{array}{c}\text { FM } \\
\text { Northern krill (15, 30, and 46\%) } \\
\text { Antarctic krill (28\%) } \\
\text { Amphipod (35\%) }\end{array}$ & 160 days & $\uparrow$ Specific growth rate \\
\hline $\begin{array}{l}\text { Yoshitomi, Aoki, } \\
\text { Oshima, \& Hata, [16] }\end{array}$ & $\begin{array}{l}5.5 \text { g rainbow } \\
\text { trout }\end{array}$ & $0,4.5,8.9$, and $17.9 \% \mathrm{KM}$ & 92 days & $\begin{array}{l}\text { Krill protein had a nutritional value } \\
\text { equivalent to fish protein }\end{array}$ \\
\hline Hansen et al. [24] & $\begin{array}{l}550 \mathrm{~g} \\
\text { Atlantic } \\
\text { salmon }\end{array}$ & $\begin{array}{c}\text { High-quality FM } \\
\text { Partially deshelled KM (75.2\%) } \\
\text { Whole KM }(68.9 \%)\end{array}$ & 100 days & $\begin{array}{c}\text { Whole KM: } \\
\downarrow \text { Growth } \\
\downarrow \text { Trypsin activity in the pyloric and mid intestine } \\
\downarrow \text { Bile acid concentration in the pylorus }\end{array}$ \\
\hline Hansen et al. [30] & $\begin{array}{l}546 \mathrm{~g} \\
\text { Atlantic } \\
\text { salmon }\end{array}$ & $\begin{array}{c}0,12.3,25.7,38.3 \text {, and } 59.8 \% \text { of } \\
\text { partially deshelled } \mathrm{KM}\end{array}$ & 100 days & $\begin{array}{c}\uparrow \text { Growth performance } \\
\uparrow \text { Lipid digestibility } \\
\uparrow \text { Fluoride in faeces } \\
\downarrow \text { Plasma cholesterol } \\
\downarrow \text { Body weight }\end{array}$ \\
\hline Roncarati et al. [21] & $\begin{array}{l}453 \mathrm{~g} \\
\text { rainbow } \\
\text { trout }\end{array}$ & $\begin{array}{l}\text { Control } \\
\mathrm{KM}(60 \%)\end{array}$ & 60 days & $\begin{array}{c}\uparrow \text { Body weight and size } \\
\downarrow \text { Perivisceral fat } \\
\downarrow \text { Visceral weight indices } \\
\uparrow \text { Omega-3 fatty acids in fillet }\end{array}$ \\
\hline
\end{tabular}

\section{FM}

Pea protein conc.

Potato protein conc.

Zhang et al. [10]

$61 \mathrm{~g}$ rainbow trout
Canola protein conc.

Soy protein conc.

All diets supplemented with $5 \%$

krill products (3.5\% KM and $1.5 \%$

krill water solubles)
Rainbow trout could utilize diets with $>95 \%$ of the protein from plant protein conc. supplemented with 72 days essential amino acids, $\mathrm{KM}$, and the water-soluble fraction of krill as feed attractant, without lowered feed intake or growth

\section{Medium FM}

Low FM

$132 \mathrm{~g}$

Kousoulaki et al. [10]
Atlantic salmon
Low krill hydrolysate (1.9\%)

High krill hydrolysate (3.8\%)

Choline chloride

Free amino acid $\uparrow$ Feed intake

42 days $\uparrow$ Appetite-stimulating effects 
TABLE 1: Continued.

\begin{tabular}{|c|c|c|c|c|}
\hline Study & Initial weight & Diets & Duration & Main krill effects \\
\hline $\begin{array}{l}\text { De Santis, Taylor, } \\
\text { Martinez-Rubio, } \\
\text { Boltana, \& Tocher, } \\
{[44]}\end{array}$ & $\begin{array}{l}\text { Fry and parr } \\
\text { Atlantic } \\
\text { salmon }\end{array}$ & $\begin{array}{l}\text { Krill oil or soybean lecithin } \\
\text { supplying phospholipid at } 2.6 \text {, } \\
3.2,3.6 \text {, and } 4.2 \% \text { of diet }\end{array}$ & $\begin{array}{l}\text { Until } \\
10 \mathrm{~g} \text { of } \\
\text { weight }\end{array}$ & $\begin{array}{l}\uparrow \text { Growth performance } \\
\text { No steatosis in the intestine }\end{array}$ \\
\hline Hatlen et al. [28] & $\begin{array}{l}104 \mathrm{~g} \text { and } \\
5527 \mathrm{~g} \\
\text { Atlantic } \\
\text { salmon }\end{array}$ & $\begin{array}{c}0 \% \mathrm{KM}+30 \% \mathrm{FM} \\
10 \% \mathrm{KM}+20 \% \mathrm{FM} \\
0 \% \mathrm{KM}+52 \% \mathrm{FM} \\
7.5 \% \mathrm{KM}+46 \% \mathrm{FM} \\
15 \% \mathrm{KM}+40 \% \mathrm{FM} \\
\end{array}$ & $\begin{array}{l}42 \text { and } \\
91 \text { days }\end{array}$ & $\begin{array}{c}\uparrow \text { Growth performance } \\
\uparrow \text { Feed intake } \\
\downarrow \text { Fat content }\end{array}$ \\
\hline Kousoulaki et al. 2018 & $\begin{array}{l}130.3 \mathrm{~g} \\
\text { Atlantic } \\
\text { salmon }\end{array}$ & $\begin{array}{c}\text { Arg } \\
\text { Arg+Ala+Pro+Leu+Phe } \\
\text { Arg+Ala+Pro+Leu+Phe+nu } \\
\text { Arg+Ala+Pro+Leu+Phe+nu+rest } \\
\text { FAA as in krill hydrolysate } \\
\end{array}$ & 83 days & $\begin{array}{c}\uparrow \text { Feed intake } \\
\uparrow \text { Growth performance } \\
\downarrow \text { Liver lipid levels } \\
\uparrow \text { Appetite-regulating neuropeptide }\end{array}$ \\
\hline Wei et al. [15] & $\begin{array}{l}102 \mathrm{~g} \\
\text { rainbow } \\
\text { trout }\end{array}$ & $\begin{array}{c}51 \% \mathrm{FM} \\
\mathrm{KM}(8.5,17.1,34.2 \text {, and } 57 \%)\end{array}$ & 56 days & $\begin{array}{l}\uparrow \text { Growth and performance } \\
\uparrow \text { Muscle pigmentation }\end{array}$ \\
\hline Jalili et al. [108] & $\begin{array}{l}\text { Fry Atlantic } \\
\text { salmon }\end{array}$ & $\begin{array}{c}25 \% \mathrm{FM} \\
17.6 \% \mathrm{FM}+7.4 \% \mathrm{KM} \\
26 \% \mathrm{FM}+23 \% \text { soya } \\
26 \% \mathrm{FM}+0.03 \text { bactocell } \\
26 \% \mathrm{FM}+0.05 \% \text { sodium butyrate }\end{array}$ & 84 days & $\begin{array}{l}\text { Altered gene expression profile of immune } \\
\text { genes in head kidney }\end{array}$ \\
\hline Mørkøre et al. [52] & $\begin{array}{l}2.3 \mathrm{~kg} \\
\text { Atlantic } \\
\text { salmon }\end{array}$ & $\begin{array}{c}15 \% \mathrm{FM}+12 \% \mathrm{FO} \\
12 \% \mathrm{KM}+5 \% \mathrm{FM}+8 \% \mathrm{FO}\end{array}$ & 84 days & $\begin{array}{c}\uparrow \text { Fillet yield } \\
\downarrow \text { Gaping } \\
\uparrow \text { Condition factor } \\
\uparrow \text { Pigmentation } \\
\uparrow \text { Firmness of the muscle } \\
\uparrow \text { Liver coloration score } \\
\downarrow \text { Fat deposition around the heart } \\
\uparrow \text { Improved gut health } \\
\uparrow \text { Compact collagen structure }\end{array}$ \\
\hline
\end{tabular}

Abbreviations: KM: krill meal; FM: fish meal; FO: fish oil; Arg: arginine; Ala: alanine; Pro: proline; Leu: leucine; Phe: phenylalanine; FAA: free amino acids; nu: nucleotides. KM inclusion levels are provided at \% of diet.

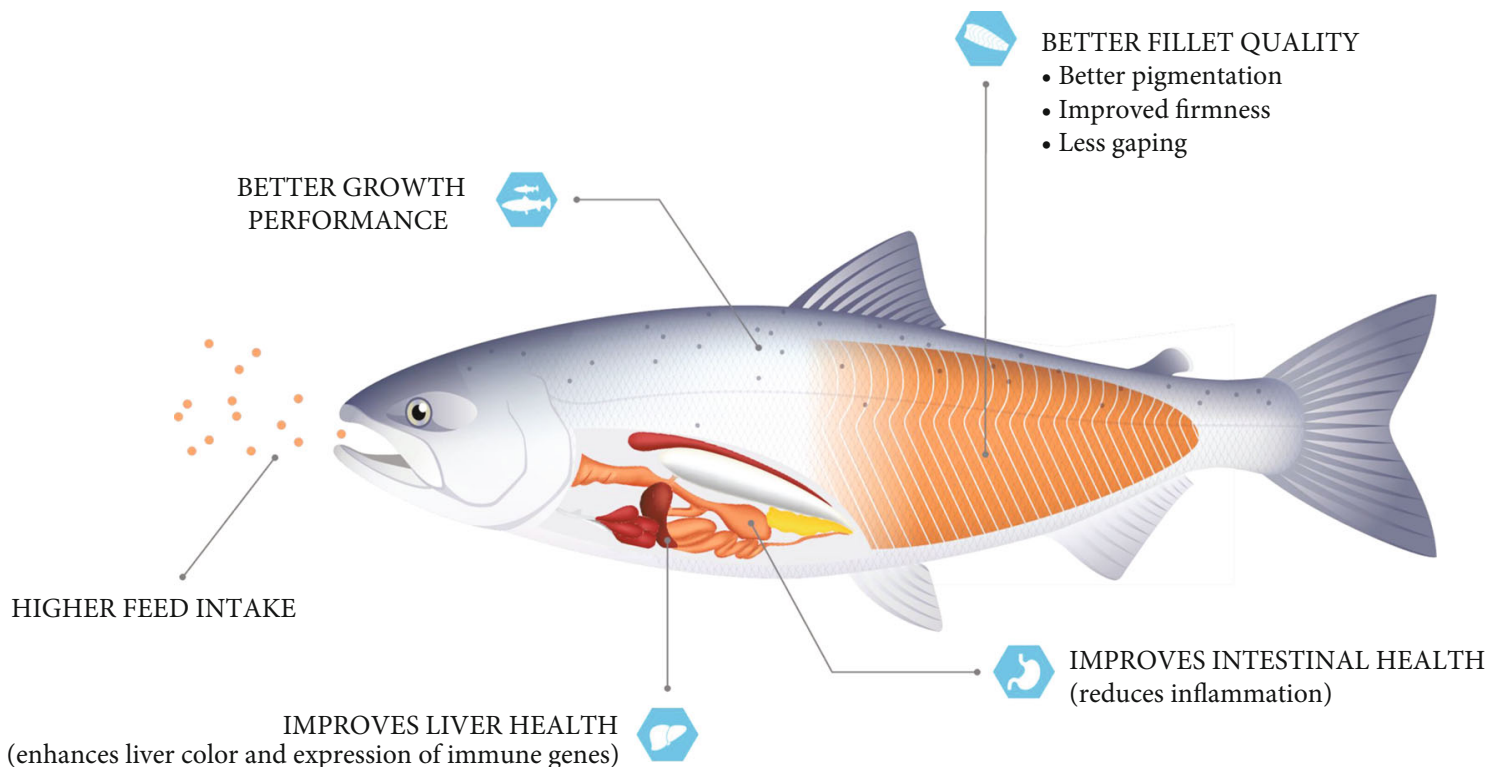

FIGURE 1: Effects of krill products on growth and robustness of salmonids. 
TABLE 2: Typical nutrient composition of krill meal.

\begin{tabular}{lc}
\hline Nutrient & Values $(\%)^{*}$ \\
\hline Fat & 25 \\
Crude protein & 58 \\
Ash & 10 \\
Water & 7 \\
Phospholipids & 43 \\
Triglycerides & 45 \\
Phosphatidylcholine & 38 \\
Cholesterol & 1.4 \\
\hline
\end{tabular}

\begin{tabular}{lc}
\hline Fatty acids (FA) (\% of extracted fat) & \\
$\mathrm{n}-3 \mathrm{FA}$ & 24 \\
$\mathrm{n}-6 \mathrm{FA}$ & 2 \\
$\mathrm{EPA}$ & 12 \\
DHA & 7 \\
\hline Astaxanthin & $124 \mathrm{mg} / \mathrm{kg}$ \\
\hline Choline & $1.3 \%$ \\
\hline
\end{tabular}

Water-soluble peptide size $\quad$ More than $50 \%$ are $<200 \mathrm{Da}$

Main amino acids (\% of crude protein)

\begin{tabular}{lc} 
Aspartic acid & 10 \\
Glutamic acid & 13 \\
Lysine & 7 \\
Leucine & 8 \\
Arginine & 6 \\
Histidine & 2 \\
Alanine & 5 \\
\hline Chitin & 4 \\
\hline Main minerals $(m g / k g)$ & \\
Calcium & 19600 \\
Phosphorus & 14200 \\
Magnesium & 4820 \\
Copper & 62 \\
Zinc & 46 \\
Iron & 33 \\
Iodine & 5 \\
Selenium & 4 \\
\hline
\end{tabular}

\begin{tabular}{lc}
\hline TMAO & $142 \mathrm{mg} \mathrm{N} / 100 \mathrm{~g}$ \\
\hline Main vitamins $(\mu \mathrm{g} / 100 \mathrm{~g})$ & 9360 \\
Vitamin E & 1250 \\
Vitamin A & 0.2 \\
Vitamin D3 & \\
\hline Nucleotides/nucleosides $(\mathrm{mg} / \mathrm{kg})$ & 1752 \\
IMP & 1374 \\
AMP & 798 \\
Inosine & 419 \\
ADP & 165 \\
Hypoxanthine & \\
\hline
\end{tabular}

*The values are obtained from the analysis of a limited number of krill meal batches. Abbreviations: EPA: eicosapentaenoic acid; DHA: docosahexaenoic acid; IMP: inosine $5^{\prime}$-monophosphate; AMP: adenosine monophosphate; ADP: adenosine diphosphate; TMAO: trimethylamine $\mathrm{N}$-oxide. between Yoshitomi et al. [16] and Wei et al. [15] could be attributed to the different water phases, where the feeding trials were conducted. In Wei et al. [15], the feeding trial was carried out with seawater rainbow trout, whereas the trial from Yoshitomi et al. [16] was conducted with freshwater rainbow trout. The fluoride from KM deposits in the bones as the fish need to accumulate minerals in the body during freshwater phase. So, the extra amount of fluoride gets deposited in bones. On the other hand, in seawater, fish excrete the extra amount of minerals in order to adjust osmotic pressure. For salmonids, high fluoride levels are suggested to decrease the growth due to its accumulation in bones, which probably distorts growth, and hence, the allowed concentrations of fluoride in the complete fish feed are prescribed at levels not more than $350 \mathrm{mg} / \mathrm{kg}$ [22]. The increased accumulation of fluoride from KM in the freshwater phase may reduce the growth, possibly explaining the results from Yoshitomi et al. [16]. This scenario was further confirmed in a later study by Yoshitomi et al.[23], where the $58 \%$ FM was completely replaced with low-fluoride KM (LFK) prepared by removing the krill exoskeleton. The aim was to decrease the fluoride content of KM ( $870 \mathrm{ppm})$ by approximately one-fourth in LFK $(230 \mathrm{ppm})$, by removing the exoskeletons from dried whole krill $[23,24]$. No negative effect on the growth performance of freshwater rainbow trout was observed with different doses of the $\operatorname{LFK}(7,15$, 30,46 , and $100 \%$ ) in comparison to the control FM [23]. These findings suggest that fluoride from KM is not deposited in the skeleton of seawater rainbow trout, allowing for higher KM inclusion levels in seawater than in freshwater diets. However, due to the limitation of cost with very high inclusion levels such as $60-100 \% \mathrm{KM}, 10-15 \%$ inclusion levels would be more feasible for the seawater phase in comparison to inclusion levels of $7-10 \%$ for the freshwater phase for a feeding period of at least 8-10 weeks.

3.2. Salmo salar (Atlantic Salmon). In more recent years, studies have also been conducted with Atlantic salmon, to determine the benefits of KM inclusion in diets (Table 1). Most of these studies found an increase in feed intake and growth performance with a partial substitution of FM with KM. For example, the study by Julshamn et al. [25] was conducted with three doses of KM $(10,20$, and $30 \%)$ and compared the growth performance to a control FM (58.6\%) diet. Only control FM and the highest KM diets $(30 \%+32.9 \%$ FM) were isonitrogenous ( $46 \%$ protein) and were fed to fish with an average weight of $500 \mathrm{~g}$ for 84 days. It was observed that feeding with 10,20 , and $30 \% \mathrm{KM}$ led to an increase in weight, and the weight gain was almost $30 \%$ higher in the groups receiving the highest levels of KM than the FM control group [25]. In addition, the SGR and condition factors were higher for the fish fed with 20 and $30 \% \mathrm{KM}$ when compared to the control FM group.

Similarly, in another study by Olsen et al. [26], five different doses of $\mathrm{KM}(20,40,60,80$, and $100 \%)$ as a partial or full replacement of FM (59.4\%) in diets for Atlantic salmon (average weight $500 \mathrm{~g}$ ) was given for 140 days. All the diets had similar levels of protein ranging between 44.6 and $45.5 \%$, and they contained the same level of soybean 
lecithin of 5\%. The replacement of FM with 20-60\% KM gave increased growth during the first 10 weeks of feeding, while no growth difference was observed during the last 69 days of feeding. Salmon that were fed 20 and $40 \%$ KM performed significantly better (SGR 0.92 and 0.88 , respectively) than the control group (0.71). However, only a nonsignificant increase in growth was observed with $60 \% \mathrm{KM}$ inclusion, when compared to the control FM group. The results from these studies were confirmed by a trial conducted by Suontama et al. [27], with KM diets that were used as partial replacement of FM (20-60\% FM replacement) given to Atlantic salmon (average weight $412 \mathrm{~g}$ ) for 160 days. All diets were isonitrogenous (46\% protein), isolipidic (25\%), and isocaloric $(24 \mathrm{MJ} / \mathrm{kg})$. Replacing $20-60 \%$ of FM with $\mathrm{KM}$ gave an increased growth rate in Atlantic salmon smolts for 100 days, in terms of fish weight and SGR (0.87 in FM vs. 0.91 in $\mathrm{KM}$ ). The results from the above-mentioned studies suggest that KM $(20-40 \%)$ as a partial FM replacement enhances the growth performance of Atlantic salmon (average initial weight between $400-500 \mathrm{~g}$ ) for feeding periods between 100 and 150 days.

In addition to the high cost, the direct protein replacement of FM by KM beyond $40 \%$ may have negative effects on the growth performance. This led to the testing of low inclusion levels, for example, in a study conducted by Hatlen et al. [28], with low inclusion levels of KM. In this study, the authors determined the effect of low KM inclusions (7.5 and $15 \%)$ on feed intake and growth performance of Atlantic salmon in two trials in seawater cages [28]. The low KM inclusion levels were balanced with other protein sources like soybean meal, corn, wheat, sunflower meal, and rapeseed protein. The first feeding trial was conducted with smolts $(104 \mathrm{~g})$ immediately after their transfer to seawater for 13 weeks. The rationale for choosing the transfer phase was to determine the effect of $\mathrm{KM}$ inclusion on the feed and growth depression faced by Atlantic salmon during the first few weeks after seawater transfer. The stimulating effect of KM led to significant increases in feed intake and growth rates, and the salmon smolts gained 29 and $40 \%$ more weight when fed 7.5 and $15 \% \mathrm{KM}$, respectively [28].

In the second trial by Hatlen et al. [28], 10\% KM inclusion was used as a partial replacement of FM in large salmon $(5500 \mathrm{~g})$ as a preslaughter diet for 10 weeks. A significant increase in yield in KM (23\% weight gain), when compared to the control $30 \%$ FM diet (20.4\% weight gain), was observed in the salmon fed with $10 \% \mathrm{KM}$. In addition to the improved growth rates, the KM-fed salmon had better quality assessments, in terms of lower intra-abdominal fat. Besides, a tendency to lower visceral fat contents was observed in the KM-fed salmon. Excess visceral fat in salmon is associated with large economic losses to the primary processing industry due to decreased slaughter yield. The results suggested that KM may stimulate growth of body length and contribute to more efficient utilization of the feed energy for protein growth rather than fat deposition. Considering the underlying mechanisms, one explanation for the leaner tissues in salmon fed the KM diet may be a stimulated $\beta$-oxidation and thereby a higher utilization of fatty acids. This scenario has been described in $\mathrm{KO}$ studies in rodents. For example, Batetta et al. [29] demonstrated that $\mathrm{KO}$ inclusion in the diets of obese rodents was effective in significantly reducing the triglyceride (TG) levels in the liver and heart tissues in comparison to the control high-fat diet, as well as the FO-supplemented diet. Besides, an effect of $\mathrm{KO}$ on endocannabinoid levels as a contributing factor for lower fat accumulation in the liver has been suggested by Batetta et al. [29]. Likewise, it is conceivable that similar mechanisms work across species, and $\mathrm{KM} / \mathrm{KO}$ leads to lower fat deposition and enhanced fatty acid oxidation also in fish, resulting in leaner tissues. However, further studies are warranted for confirmation.

Similar to what has been observed in rainbow trout studies, the total substitution of FM in salmon diets with whole KM $(925 \mathrm{~g} / \mathrm{kg})$ led to reduced growth [24]. But when the krill was deshelled and partially deshelled KM (PDKM, $964 \mathrm{~g} / \mathrm{kg}$ ) was added, then no reduction in growth was seen. This suggests that compounds in the shell, such as chitin, fluoride, or ash, are responsible for the growth depression with very high inclusion levels of KM. Indeed, Hansen et al. [24] found an elevation in bone fluoride when whole KM was fed, reaching $18.4 \mathrm{mg} / \mathrm{kg}$ dry weight, whereas the fluoride levels in the bone tissue were similar between PDKM $(7.27 \mathrm{mg} / \mathrm{kg}$ dry weight) and control FM ( $8.64 \mathrm{mg} / \mathrm{kg}$ dry weight) diets. On the contrary, Julshamn et al. [25] found no difference in bone fluoride levels between $\mathrm{KM}$ (30\% KM and 32.9\% FM) and control FM (58.6\%) diets. The bone fluoride values were 6.9 and $6.5 \mathrm{mg} / \mathrm{kg}$ for the $\mathrm{KM}$ and FM diets, respectively. Interestingly, a $29 \%$ increase in weight gain in the salmon fed with the KM diet (SGR $=0.81 \%$ ) compared to the control FM (SGR $=0.64 \%)$ diet was observed [25]. Similarly, a trial with Atlantic salmon smolts (546 g) with different inclusion levels of PDKM as a replacement of FM found a growth enhancement with all KM inclusion levels in the first 56 days of the trial. Based on the results, an inclusion level of $40 \%$ PDKM was suggested for an optimal growth [30]. In addition to increased growth, the lipid digestibility was found to increase with increasing levels of PDKM (97.1\%) in comparison to the control FM diet (93.2\%), with a parallel decline in starch digestibility (60.5\% for PDKM vs. $74.3 \%$ for the FM diet). The increase in lipid digestibility could be due to the higher levels of PL in the diets with PDKM. The TG/PL ratio in the residual lipid content in FM is about 2:1 of total lipids [31]. This led Hansen et al. (2011) to suggest that the FM control and the highest PDKM diet contained approximately 5 and $15 \%$ PL of total lipids, respectively. The amount of PL in Antarctic krill has been reported to be between 41 and $54 \%$ of the total lipid content [32]. PL act as surfactants in the intestine during lipid digestion and may thus improve lipid emulsification and increase lipid digestibility in fish $[31,33]$.

Lower growth performance in salmonids, with very high $\mathrm{KM}$ inclusions, may also be related to increased content of indigestible compounds such as chitin. Chitin has the ability to form ionic bonds with lipid and bile so that they escape hydrolysis by lipases leading to lower lipid absorption [34]. This complements well with the studies, where very high KM inclusions ( 80 and 100\%) have been shown to have poor feed conversions along with lower lipid digestibility and 
increased fecal moisture content [26]. Moreover, reduced growth with increasing dietary addition of pure chitin was seen in salmon, resulting in fish fed diets with 0 or $1 \%$ chitin achieving a higher final weight than those fed 2 or $5 \%$ chitin [35].

The cited studies provide decent documentation for a positive effect of partial substitution of FM with KM (7$30 \%$ of the diet) on the growth rate in different life stages of Atlantic salmon, while at higher inclusions (60-100\%) growth was negatively affected. The increased feed intake seems to be associated with a positive effect on growth in many studies. Feed attractant properties of KM are due to the high proportion of water-soluble components, free amino acids (such as alanine, proline, arginine, glutamine, leucine, and glycine), short peptides, nucleotides, and trimethylamine $\mathrm{N}$-oxide (TMAO), which are known to have appetite regulative functions in fish $[10,36]$. Free amino acid mixes, nucleotides, and choline chloride or betaine are often used as feeding stimulants at the early life stages of aquatic organisms. However, it could be the combination with the nutritional benefits of KM ( $n-3$ fatty acids, PL, astaxanthin, and the well-balanced amino acid profile) that leads to enhanced growth. For example, the major PL present in krill products is PC [37]. Choline, as part of PC, is essential for de novo synthesis of PL, betaine, and the neurotransmitter acetylcholine. Choline deficiency results in liver dysfunction in different species [38] [39, 40]. Fish fed choline-deficient diets demonstrated reduced feed intake, growth, and survival [41]. Recently, it has been revealed that dietary choline prevents excessive lipid accumulation in the intestine and is essential for Atlantic salmon in seawater [38].

In addition to $\mathrm{KM}, \mathrm{KH}$ and $\mathrm{KO}$ have been used to some extent in aquaculture. There is limited scientific literature available on $\mathrm{KH}$. For example, in a trial with Atlantic salmon, Kousoulaki et al. [10] tested the addition of 1.9 and $3.8 \% \mathrm{KH}$ to a high-plant protein diet with $3 \% \mathrm{FM}$ (Table 1). This study showed that $\mathrm{KH}$ supplementation had a positive effect on feed intake with a $16 \%$ increase in the $3.8 \% \mathrm{KH}$ diet group when compared to the control group. A similar positive effect on growth performance with both inclusion levels of $\mathrm{KH}$ was also observed [10]. Oikawa and March [42] reported improvements in feed intake and growth in three short-term trials (19-30d) with juvenile rainbow trout when $\mathrm{KH}$ was added [42]. In a recent study, it has been demonstrated that KM is already highly hydrolyzed, with $>75 \%$ peptides below $1 \mathrm{kDa}$, which is one of the main factors for enhancing the feed intake and as a result the growth performance with $\mathrm{KM}$ inclusion [43]. It would be interesting to determine if hydrolyzing KM completely would further increase these effects and a direct comparison of $\mathrm{KM}$ and $\mathrm{KH}$ on feed intake and growth performance is warranted.

$\mathrm{KO}$ is a richer source of PC when compared to soy lecithin. Besides, KO has a high proportion of n-3 PUFAs, whereas soy lecithin is rich in $n-6$ PUFAs. PC is the main PL present in $\mathrm{KO}$ and accounts for $>80 \%$ PL. Soybean lecithin, on the other hand, contains around $62 \%$ total PL, which includes $45 \%$ PC. In addition, soy lecithin contains $5 \%$ TG. Contrary to KO, soy lecithin does not contain
EPA and DHA [44]. Soy lecithin is rich in n-6 fatty acid linoleic acid (40.2\%) and contains oleic acid (10.6\%), which is an n-9 monosaturated fatty acid and the n-3 fatty acid linolenic acid (2\%). $\mathrm{KO}$ on the other hand is rich in $\mathrm{n}-3$ PUFAs, with an average of 12\% EPA and 6\% DHA (Table 2). Their direct comparison has been studied by Taylor et al. [45] in Atlantic salmon in the fry stage. The authors found that mortality and prevalence of vertebral deformities decreased with increasing dietary PL. The highest growth was achieved in fish fed krill PL at $2.6 \%$ and in fish fed soy lecithin at 3.6\%. The study further demonstrated that KO was more efficient than soy lecithin in reducing intestinal steatosis. Interestingly, similar results have been observed in marine fish species [46], where it was found that inclusion of $\mathrm{KO}$ improved larval sea bream growth in terms of weight and length, enhanced hepatic utilization of dietary lipids, and reduced the incidence of enterocyte injuries, in comparison to soy lecithin [46].

Based on the above-mentioned studies, deshelled KM inclusion in salmonid feed is suggested to be beneficial for enhancing feed intake and growth performance of fish in both freshwater and seawater. However, considering the cost factor, $8-10 \%$ for $10-12$ weeks is suggested to be sufficient to achieve growth performance benefits. In addition, deshelled $\mathrm{KM}$, the main krill product available for aquaculture, is a sustainable and a palatable source of various high-quality nutrients as described in Table 2. Hence, $\mathrm{KM}$ is used as a substitute of FM not only as a protein source but also for PL, n-3 fatty acids, astaxanthin, etc.

\section{Effects of Krill on Fillet Quality}

Texture, firmness, and color of Atlantic salmon fillets are the major parameters that determine the consumer satisfaction [47], which are not inherently interrelated parameters [48]. Fillets with quality deviations such as gaping, soft flesh, and dark melanin spots are main causes to quality downgrading of farmed salmon, because of consumer rejection $[49,50]$, and lead to substantial economic losses in the salmon industry [49-51]. Loss of fillet firmness is associated with increasing percentage of soluble collagen and a decreasing percentage of insoluble collagen [52]. Collagen is the most abundant protein in intramuscular connective tissue and consists of a helical structure of three polypeptide chains. Mechanical strength of connective tissue is provided by cross-links between collagen and elastin molecules. A recent Atlantic salmon study [53] showed improved fillet firmness and integrity with KM inclusion. In the study, two test diets were compared for their efficacy on the fillet quality of preslaughter salmon (initial weight of $270 \mathrm{~g}$ ) when given for three months. Both diets were isoproteinic (35\%) and isolipidic (35\%), with one diet of 15\% FM and 10\% FO and the other diet with $12 \% \mathrm{KM}, 5 \% \mathrm{FM}$, and $8 \% \mathrm{FO}$. Both these test diets were lower in FM and FO levels in comparison to the earlier published studies on salmonids $[26,28]$. The authors demonstrated a reduction in gaping by supplementing salmon finishing diets with $12 \% \mathrm{KM}$ and showed a lower presence of single $\alpha$-helix, lower random coil, and lower disordered structures in collagen molecules 
of salmon fed dietary KM, which indicated a higher preservation of collagen native structure in contrast to the fish fed with FM. Taken together, these findings indicate that dietary KM has a positive effect on maintaining the native collagen structure, which is important for muscle integrity and firmness and in reducing gaping issues [53]. Moreover, the authors found a significant increase in the genes coding for different forms of myosin heavy chain. In as much, myomesin-2, which is a gene encoding a protein responsible for the elastic behavior of the myocyte [54], showed a 1.5-fold increased expression in the KM group compared with the FM group. This finding was in alignment with the findings of an earlier study, where it has been shown that soft flesh of Atlantic salmon has been associated with myocyte detachment and altered extracellular matrix protein distribution [49].

\section{Effects of Krill on Pigmentation}

Astaxanthin $\left(3,3^{\prime}\right.$-dihydroxy- $\beta, \beta^{\prime}$-carotene- $4,4^{\prime}$-dione $)$ is a carotenoid that is synthesized by photosynthetic bacteria, algae, and yeast. Because krill eat microalgae, $\mathrm{KM}$ is rich in astaxanthin with most in the diesterified form, where both hydroxyl groups are esterified with a fatty acid [55]. Synthetic astaxanthin contains only the nonesterified form with both hydroxyl groups unmodified. Besides the differences in esterification, astaxanthin exists as three different optical isomers, with mainly the $3 \mathrm{R}, 3^{\prime} \mathrm{R}$ optical isomer form found in KM (62-71\% 3R, $3^{\prime} \mathrm{R}$ and $\left.11-14 \% 3 \mathrm{~S}, 3^{\prime} \mathrm{R}\right)$ [55] and the meso form in synthetic astaxanthin (3S, $3^{\prime} \mathrm{S}:$ meso: $3 \mathrm{R}, 3^{\prime}$ $\mathrm{R}=1: 2: 1$ ) [56]. The optical isomer structure is maintained intact when incorporated into flesh or skin of fish $[57,58]$. But there are no indications in the literature that the different optical isomers of astaxanthin have different metabolic effects.

Carotenoids cannot be synthesized by salmonids, so they rely upon supplementation in feed to ensure redness of the flesh. Given that the distinctive color of salmon flesh is an important factor for consumer acceptability, it is standard practice in the aquaculture industry to supplement salmonid feeds with carotenoids such as astaxanthin in order to pigment their flesh to a color comparable to wild fish $[59,60]$ As per EFSA, the maximum limit for synthetic astaxanthin in salmonid diets is $100 \mathrm{mg} / \mathrm{kg}$ [61]. Moreover, astaxanthin has documented effects as an antioxidant $[62,63]$, through singlet oxygen quenching $[64,65]$ and anti-inflammatory properties [66]. Astaxanthin is also a precursor for vitamin A [67] and is crucial for fertility and reproductive performance in several fish species [68-70]. In Atlantic salmon, fertility and reproductive performance was not shown to be affected by astaxanthin [71]; however, dietary astaxanthin was shown to be essential for normal growth in juvenile salmon [72].

In a number of studies, it has been shown that the dietary inclusion of KM imparts coloration to the flesh of salmonids. An example is Suontama et al. [27], where salmon were fed for 160 days a diet containing $28 \% \mathrm{KM}$, replacing $40 \%$ of the FM and providing $26 \mathrm{mg} / \mathrm{kg}$ astaxanthin esters and $1.4 \mathrm{mg} / \mathrm{kg}$ free astaxanthin [27]. This diet also contained $40 \mathrm{mg} / \mathrm{kg}$ synthetic astaxanthin, resulting in a total astaxanthin content of $67.4 \mathrm{mg} / \mathrm{kg}$ in the feed. For comparison, another group of fish received a diet containing $61.1 \%$ FM and $64 \mathrm{mg} / \mathrm{kg}$ synthetic astaxanthin. At the end of the trial, astaxanthin content in the fillets was the same between the fish receiving diets containing $\mathrm{KM}$ compared to the fish receiving diets containing a comparable amount of total astaxanthin (i.e., approximately $4 \mathrm{mg} / \mathrm{kg}$ tissue in both groups). The coloration of the fish flesh was also not significantly different between the two groups, supporting that $\mathrm{KM}$ can serve as a replacement for synthetic astaxanthin as a pigment source.

In another study in rainbow trout by Scott et al. [59], it was shown that feeding KM at a level of $29 \%$ of the diet, replacing $60 \%$ of the FM in the basal diet and providing $60 \mathrm{mg} / \mathrm{kg}$ feed of astaxanthin, resulted in an increased astaxanthin deposition in fillets when compared to trout fed a control FM-based diet. The astaxanthin levels were reported to be $7 \mathrm{mg} / \mathrm{kg}$ in the fillets from KM-fed fish and $<1 \mathrm{mg} / \mathrm{kg}$ in the fillets from control fish. The increase in astaxanthin deposition was accompanied by an increase in redness of fillets from trout fed the KM compared to control fillets [59]. Hence, the observations from Suontama et al. [27] and Schott et al. (1995) indicate that KM could serve as natural source of astaxanthin to enhance the fillet pigmentation.

The study by Roncarati et al. [21] investigated the effects on fillet pigmentation of rainbow trout by dietary inclusion of $60 \% \mathrm{KM}$ providing $90 \mathrm{mg} / \mathrm{kg}$ astaxanthin. The control group received a diet composed of FM, wheat meal, and soybean meal supplemented with $90 \mathrm{mg} / \mathrm{kg}$ of synthetic astaxanthin. Dietary inclusion of KM resulted in astaxanthin deposition ( $4.3 \mathrm{mg} / \mathrm{kg}$ tissue) that was slightly, but significantly lower than in the control fish $(5.4 \mathrm{mg} / \mathrm{kg}$ tissue). Accordingly, a lighter pink-red color was observed in the fillet of fish fed diets containing KM compared to a commercial diet formulated with synthetic astaxanthin [21]. Nevertheless, the authors noted that despite the lighter coloration, the amount of carotenoids and astaxanthin provided by the $\mathrm{KM}$ was considered to be adequate for the pigmentation of rainbow trout and that the resulting concentration of astaxanthin in the flesh under the conditions tested is within those reported in the flesh of wild salmon (i.e., 4 to $34 \mathrm{mg} / \mathrm{kg}$; U.S. FDA, 1995). Similarly, in a study on Atlantic salmon [53], authors investigated the efficacy of two isoproteinic (35\%) and isolipidic (35\%) diets, FM (15\%) with $12 \% \mathrm{KM}$, for a feeding period of three months, in enhancing fillet pigmentation. KM was found to significantly improve the overall color, with all fillets of the KM group having a SalmoFan score $\geq 25$, while $13 \%$ of the FM group showed a SalmoFan score below the general acceptance level. The results of the above studies demonstrate that astaxanthin present in $\mathrm{KM}$ is transferred to the fillets of salmonids.

Based on the above-mentioned studies and considering the cost factor associated with KM, an inclusion level of $10-15 \%$ is suggested to enhance the fillet pigmentation in salmonids. In addition, KM contains other active substances that might be of benefit, such as vitamin E, A, and B12 [8]. 


\section{Effects of Krill on Liver and Intestinal Health}

The dietary lipid composition has been shown to affect the lipid class and fatty acid composition in salmonids $[26,45$, $46,73,74]$. Studies described that feeding diets deficient in PL or the use of terrestrial plant lipids, such as soybean lecithin and rapeseed lecithin (n-6 rich PL), which are relatively cheaper PL sources than KM and are commonly used in feeds, resulted in intestinal and liver steatosis in fish with accumulation of lipid vacuoles or droplets in enterocytes and higher lipid deposition in the hepatocytes. The observations of the above-mentioned studies suggest that dietary n$3 \mathrm{PL}$ are required for the efficient export of dietary lipids from the liver and intestine [26, 45, 46, 73-75]. Besides, the dietary choline has also been shown to prevent excessive lipid accumulation in the intestine of Atlantic salmon [38]. Recently, it has been shown that a 12\% KM inclusion in feed led to a reduction in liver paleness in Atlantic salmon [53]. Pale liver is associated with nutritional disorders as this organ is involved in an array of metabolic and homoeostatic functions [76]. In addition to a reduction of the hepatic fat content, the authors also observed a significant reduction of fatty hearts in Atlantic salmon fed dietary KM. This indicates that the PL fraction of KM has the ability to influence lipid transport and deposition in different organs. The microarray analysis of the liver tissues, in the study by Mørkøre et al. [53], revealed a higher expression (2.4-fold higher) of cadherin-13 in the liver of fish fed KM [53]. Cadherin-13 is associated with the circulating levels of the adipocyte-secreted protein adiponectin, which has antiinflammatory potential and plays an important role in metabolic regulation, related to the fatty liver index in humans [77]. In addition to the effects in the liver, krill PL appeared to reduce inflammation and improve gut health, with no ectopic epithelial cells and focal calcium deposits observed in intestinal tissues in $\mathrm{KM}$-fed salmon in comparison to 15\% FM-fed fish that showed both ectopic epithelial cells and focal calcium deposits in intestinal tissues [53]. It is known that focal accumulation of calcium deposits in necrotic tissue is related to intestinal inflammation in Atlantic salmon [78], and the presence of ectopic epithelial cells in the intestine has been associated with chronic feed-induced gut inflammation associated with plant-based ingredients $[79,80]$. Taken together, KM inclusion is beneficial in lowering liver and intestinal lipids, and it seems that not only the amount of PL but also the source of PL is important in reducing the lipid accumulation in the liver and intestine. Based on the above-mentioned studies, it can be suggested that an inclusion level of $10-15 \% \mathrm{KM}$ in salmonid diets is beneficial in enhancing intestinal health through the reduction of lipid levels.

\section{Effects of Krill on Microbiota}

From human medicine, it is well established that the gut microbiota plays a pivoting role for proper gut function and health relating to processes such as protection from pathogens, immune responses, nutrition, and metabolism [81-84]. Similar to that of mammals, the salmonid intestinal microbiota composition shows a spatial heterogeneity [85, $86]$ and can be influenced by a number of factors, such as diet $[85,87,88]$, developmental stage [89], rearing environment [90], antibiotics [91], and genetics [92]. Diet is probably among the most important factors to shape the gut microbiota. Different components of dietary origin may selectively promote or suppress the growth of certain microbial clades, which in turn could induce profound effects on host health and, ultimately, its ability to combat disease. However, only a few studies to date have investigated potential relationships between diet, gut microbial community composition, and host function in salmonids [85, 93].

Chitin may function as prebiotic and may selectively promote the growth of certain intestinal microbes, which have the potential to prevent growth and colonization of pathogenic bacteria in the digestive tract [94]. For example, chitin has been shown to have protective effects against a Vibrio alginolyticus infection in white shrimp [95]. Chitin is an essential component of the krill exoskeleton, and $\mathrm{KM}$ contains therefore around $2-4 \%$ of chitin. Ring $\varnothing$ et al. [94] evaluated the effects of dietary chitin from KM supplementation on mucosa-associated bacteria composition in the distal intestine of Atlantic salmon [94]. The study included two test diets: one control diet contained $58.9 \% \mathrm{FM}$ as protein source, while the other diet contained a $1: 1 \mathrm{mix}$ (32\%:32\% of the diet) of FM and KM. The authors demonstrated that the adherent microbiota profile was modulated by $\mathrm{KM}$ inclusion. Only in fish fed the KM diet were no Gram-positive bacteria such as Carnobacterium piscicola, Microbacterium oxydans, Microbacterium luteolum, and Staphylococcus equorum spp. linens and the Gramnegatives Psychrobacter spp. and Psychrobacter glacincola detected. However, how these changes influence the intestinal condition and eventually the growth and health of salmon warrants further studies. Chitin is also a wellknown immune stimulant. Sakai [96] demonstrated that chitin injection in rainbow trout stimulated macrophage activities and increased resistance towards Vibrio anguillarum infection. However, whether chitin from dietary KM supplementation could provide such resistance to rainbow trout merits further investigation.

\section{Suggestions for Future Studies}

The current literature lacks complete documentation on the effects of KM covering all the different developmental stages of salmonids to cover the total production cycle. Antarctic krill is a sustainable marine ingredient, with a good package of high-quality nutrients. A relevant area for future research would therefore be to include KM in sustainable diets (low FM and FO) and determine the effects on feed intake and growth performance of salmonids at different developmental stages. In addition, salmonid diets should be as low as possible in both FM and FO since the present stocks cannot sustain the increasing demands of a growing aquaculture [97]. Further, for how long the weight gained by adding dietary KM during a short period, e.g., when used in seawater transfer feeds, is preserved during the rest of the production cycle would be an interesting subject for future studies. Moreover, 
studies are needed to decipher the underlying biochemical and signaling pathways involved in enhancing feed intake, growth performance, and digestibility in salmonids. It has been reported that krill extract stimulated gastric and intestinal enzyme secretion and increased protein digestibility in yellowtail [98]. However, current literature lacks similar documentation in salmonids.

There are few studies that investigated the effect of KM on digestibility. For example, Olsen et al. [26] compared the protein, lipid, and dry matter digestibility with different doses of KM (20-100\%). The authors found a trend towards lower lipid digestibility with higher KM inclusions (80$100 \%$ ) due to higher chitin levels. However, digestibility of dry matter and protein was not influenced by high KM inclusion levels [26]. On the contrary, Hatlen et al. (2017) found a decreased protein digestibility with KM (7.5 and $15 \%)$ in comparison to FM (30\%), whereas no difference between lipid digestibility was observed between the KM and control FM diets [28]. However, the effect of KM on gastric and intestinal enzyme secretion is not yet documented in salmonids. Furthermore, studies are warranted to understand how KM can influence the expression of neuropeptides to regulate hunger and appetite stimulation in salmonids.

Both farmed and wild salmon have been shown to accumulate a variety of toxic pollutants, such as dioxins and polychlorinated biphenyls (PCBs). Some of these toxic pollutants may counteract the beneficial effects of the n-3 PUFAs present in fish and may increase the risk of other diseases [99]. The European Food Safety Authority (EFSA) has cited FM and FO as contributors to higher levels of PCBs and dioxins in the food chain. As per the EFSA recommendations, based on the tolerable weekly intake of PCBs and dioxins, weekly intake of salmon has decreased from $1300 \mathrm{~g}$ to $185 \mathrm{~g} /$ week for an adult individual $(70 \mathrm{~kg})$ and decreased from $630 \mathrm{~g}$ to $90 \mathrm{~g}$ for a child (35 kg) [100]. However, a decrease in the weekly intake of salmon would be compromising the amount of n-3 long-chain PUFAs. Hence, it would be interesting to determine if KM could be a solution to this compromise, since KM belongs to the second lowest trophic level in the marine food chain providing clean marine ingredients. Recently, a study assessed the plastic content in 26 different commercial FM products, from 11 countries, and KM from Antarctica. A wide range of plastic content was found in all the FM samples, whereas no plastic was detected in KM [101].

Another interesting aspect could be to determine the effects of KM on broodstock and egg quality. Unpredictable and variable egg quality is a major limiting factor for successful mass production of fish fry, and a lack of highquality formulated feed for broodstock partly accounts for bad reproductive performance. It has been demonstrated that egg composition and spawning quality of gilthead sea bream are directly affected by n-3 PUFA content of broodstock diets. Inclusion of raw krill in red sea bream broodstock has been shown to improve spawning quantity and quality in terms of buoyant eggs, total hatch, and normal larvae [102]. Similarly, for Atlantic halibut, a diet for broodstock containing KM performed equally well, in terms of fecundity and fertilization rates, when compared to a diet supplemented with tuna orbital oil [103]. However, the current literature lacks such documentation with salmonids.

Further, the immunostimulant properties of KM make it a relevant functional ingredient to be tested against sea lice, as many studies have shown beneficial effects of immunostimulants, most important the beta glucans, in reducing sea lice infestation rates of Atlantic salmon, both experimentally and on farms $[104,105]$.

\section{Conclusions}

The present review summarized the documented benefits of Antarctic krill products (KM, KO, and $\mathrm{KH}$ ) on feed intake, growth performance, fillet quality, and robustness of salmonids. Among the different krill products, KM has been the most vastly studied product with positive effects on feed intake, growth performance, fillet quality, and liver and intestinal health. More studies are needed to deepen the knowledge on the benefits of krill in salmonids and the biological pathways involved. Besides, the effect of krill products on broodstock performance and resistance towards different parasites and pathogens would merit future studies.

\section{Conflicts of Interest}

The authors declare that they have no conflicts of interest.

\section{Acknowledgments}

We are very grateful to Bjarne Hatlen, a senior scientist from NofimaAS, whose report on the effects of KM and KO on feed intake and growth performance in salmonids was used as a base for this review.

\section{References}

[1] V. Spiridonov and B. Casanova, "Order Euphausiacea Dana, 1852," in Treatise on Zoology-Anatomy, Taxonomy, Biology. The Crustacea, vol. 9, pp. 5-82, Brill, 2010.

[2] A. Atkinson, V. Siegel, E. Pakhomov, M. Jessopp, and V. Loeb, "A re-appraisal of the total biomass and annual production of Antarctic krill," Deep Sea Research Part I: Oceanographic Research Papers, vol. 56, no. 5, pp. 727-740, 2009.

[3] S. Nicol and J. Foster, "The fishery for Antarctic krill: its current status and management regime," in Biology and Ecology of Antarctic Krill, V. Siegel, Ed., Advances in Polar Ecology. Springer, Cham, 2016.

[4] G. Macaulay, G. Skaret, T. Knutsen, O. Bergstad, B. Krafft, and S. Fielding, Biomass results from the International Synoptic Krill Survey in Area 48, 2019. SG-ASAM-2019/08, CCAMLR, 2019.

[5] S. Nicol and Y. Endo, Krill Fisheries of the World, Food \& Agriculture Org. Tech, 1997.

[6] S. Nicol, I. Forster, and J. Spence, "Products derived from krill," Krill: Biology, ecology and fisheries, vol. 6, pp. 262$283,2000$.

[7] T. Storebakken, "Krill as a potential feed source for salmonids," Aquaculture, vol. 70, no. 3, pp. 193-205, 1988. 
[8] J. C. Tou, J. Jaczynski, and Y.-C. Chen, "Krill for human consumption: nutritional value and potential health benefits," Nutrition Reviews, vol. 65, no. 2, pp. 63-77, 2007.

[9] J. W. Hertrampf and F. Piedad-Pascual, Handbook on Ingredients for Aquaculture Feeds, Springer Science \& Business Media, 2012.

[10] K. Kousoulaki, I. Rønnestad, H. Olsen et al., "Krill hydrolysate free amino acids responsible for feed intake stimulation in Atlantic salmon (Salmo salar)," Aquaculture Nutrition, vol. 19, pp. 47-61, 2013.

[11] F. Jahn, M. Lukowicz, and R. Lörz, "Erfahrungen mit krillmehl im forellenfutter," Fischer und Teichwirt, vol. 29, pp. 67-68, 1978.

[12] E. Pfeffer and K. Becker, "Studies on the feeding value of some commercial trout feeds and on replacing a major part of fish meal by krill meal in trout feed," Archiv fuer Fischereiwissenschaft, vol. 28, no. 1, pp. 19-29, 1977.

[13] H. Beck, H. Koops, K. Tiews, and J. Gropp, "Further possibilities for replacing fish meal in rainbow trout feeds: replacement of fish meal by alkane yeast and krillmeal," Archiv fuer Fischereiwissenschaft, vol. 28, no. 1, pp. 1-17, 1977.

[14] H. Koops, K. Tiews, J. Gropp, and H. Beck, Krill in trout diets. Paper presented at the FAO, Rome (Italy), Symposium on Finfish Nutrition and Feed Technology, Hamburg (Germany, FR), 1978.

[15] Y. Wei, H. Chen, M. Jia et al., "Effects of dietary Antarctic krill Euphausia superba meal on growth performance and muscle quality of triploid rainbow trout Oncorhynchus mykiss farmed in sea water," Aquaculture, vol. 509, pp. 72-84, 2019.

[16] B. Yoshitomi, M. Aoki, S.-I. Oshima, and K. Hata, "Evaluation of krill (Euphausia superba) meal as a partial replacement for fish meal in rainbow trout (Oncorhynchus mykiss) diets," Aquaculture, vol. 261, no. 1, pp. 440-446, 2006.

[17] T. Papuktchieva, H. Tomassian, A. Zaikov, M. Gadjeva, M. Simovska, and Z. Ribarov, "Testing of combined granules, containing krill meal, for feeding carp and trout for consumption," Proceedings of the freshwater fishery research station, Plovdiv, vol. 15, pp. 79-107, 1981.

[18] B. Vens-Cappell and H. Horstmann, "Untersuchungen über die eignung des krillmehls als ersatz für fischmehl im trockenmischfutter für forellen," Österreichische Fischerei, vol. 31, pp. 35-46, 1978.

[19] T. Soevik and O. Braekkan, "Fluoride in Antarctic krill (Euphausia superba) and Atlantic krill (Meganyctiphanes norvegica)," Journal of the Fisheries Board of Canada, vol. 36, no. 11, pp. 1414-1416, 1979.

[20] K. Tiews, M. Manthey-Karl, and H. Koops, The carry-over of fluoride from krill meal pellets into rainbow trout (Salmo gairdneri), vol. 32, no. 1-3, 1982Inst. für Küsten-u. Binnenfischerei. ARCH. FISCHEREIWISS, 1982.

[21] A. Roncarati, F. Sirri, A. Felici, L. Stocchi, P. Melotti, and A. Meluzzi, "Effects of dietary supplementation with krill meal on pigmentation and quality of flesh of rainbow trout (Oncorhynchus mykiss)," Italian Journal of Animal Science, vol. 10, no. 2, 2011.

[22] J. L. Metcalfe-Smith, K. E. Holtze, G. R. Sirota, J. J. Reid, and S. R. de Solla, "Toxicity of aqueous and sediment-associated fluoride to freshwater organisms," Environmental Toxicology and Chemistry: An International Journal, vol. 22, no. 1, pp. 161-166, 2003.
[23] B. Yoshitomi, M. Aoki, and S.-I. Oshima, "Effect of total replacement of dietary fish meal by low fluoride krill (Euphausia superba) meal on growth performance of rainbow trout (Oncorhynchus mykiss) in fresh water," Aquaculture, vol. 266, no. 1-4, pp. 219-225, 2007.

[24] J. Ø. Hansen, M. Penn, M. Øverland et al., "High inclusion of partially deshelled and whole krill meals in diets for Atlantic salmon (Salmo salar)," Aquaculture, vol. 310, no. 1-2, pp. 164-172, 2010.

[25] K. Julshamn, M. K. Malde, K. Bjorvatn, and P. Krogedal, "Fluoride retention of Atlantic salmon (Salmo salar) fed krill meal," Aquaculture Nutrition, vol. 10, no. 1, pp. 9-13, 2004.

[26] R. Olsen, J. Suontama, E. Langmyhr et al., "The replacement of fish meal with Antarctic krill, Euphausia superba in diets for Atlantic salmon, Salmo salar," Aquaculture Nutrition, vol. 12, no. 4, pp. 280-290, 2006.

[27] J. Suontama, Ø. Karlsen, M. Moren et al., "Growth, feed conversion and chemical composition of Atlantic salmon (Salmo salar L.) and Atlantic halibut (Hippoglossus hippoglossus L.) fed diets supplemented with krill or amphipods," Aquaculture Nutrition, vol. 13, no. 4, pp. 241-255, 2007.

[28] B. Hatlen, K. Berge, S. Nordrum, K. Johnsen, K. Kolstad, and T. Mørkøre, "The effect of low inclusion levels of Antarctic krill (Euphausia superba) meal on growth performance, apparent digestibility and slaughter quality of Atlantic salmon (Salmo salar)," Aquaculture Nutrition, vol. 23, no. 4, pp. 721-729, 2017.

[29] B. Batetta, M. Griinari, G. Carta et al., "Endocannabinoids may mediate the ability of (n-3) fatty acids to reduce ectopic fat and inflammatory mediators in obese Zucker rats," The Journal of Nutrition, vol. 139, no. 8, pp. 1495-1501, 2009.

[30] J. Ø. Hansen, K. D. Shearer, M. Øverland et al., "Replacement of LT fish meal with a mixture of partially deshelled krill meal and pea protein concentrates in diets for Atlantic salmon (Salmo salar)," Aquaculture, vol. 315, no. 3-4, pp. 275-282, 2011.

[31] D. R. Tocher, E. Å. Bendiksen, P. J. Campbell, and J. G. Bell, "The role of phospholipids in nutrition and metabolism of teleost fish," Aquaculture, vol. 280, no. 1-4, pp. 21-34, 2008.

[32] A. Clarke, "Lipid content and composition of Antarctic krill, Euphausia superba Dana," Journal of Crustacean Biology, vol. 4, no. 5, pp. 285-294, 1984.

[33] S. Hung, G. Berge, and T. Storebakken, "Growth and digestibility effects of soya lecithin and choline chloride on juvenile Atlantic salmon," Aquaculture Nutrition, vol. 3, no. 2, pp. 141-144, 1997.

[34] G. Lindsay, "Distribution and function of digestive tract chitinolytic enzymes in fish," Journal of Fish Biology, vol. 24, no. 5, pp. 529-536, 1984.

[35] Ø. Karlsen, H. Amlund, A. Berg, and R. E. Olsen, "The effect of dietary chitin on growth and nutrient digestibility in farmed Atlantic cod, Atlantic salmon and Atlantic halibut," Aquaculture Research, vol. 48, no. 1, pp. 123-133, 2017.

[36] P. Li, K. Mai, J. Trushenski, and G. Wu, "New developments in fish amino acid nutrition: towards functional and environmentally oriented aquafeeds," Amino Acids, vol. 37, no. 1, pp. 43-53, 2009.

[37] E. Albessard, P. Mayzaud, and J. Cuzin-Roudy, "Variation of lipid classes among organs of the Northern krill Meganyctiphanes norvegica, with respect to reproduction," Comparative 
Biochemistry and Physiology Part A: Molecular \& Integrative Physiology, vol. 129, no. 2-3, pp. 373-390, 2001.

[38] A. K. Hansen, T. M. Kortner, V. Denstadli et al., "Doseresponse relationship between dietary choline and lipid accumulation in pyloric enterocytes of Atlantic salmon (Salmo salar L.) in seawater," British Journal of Nutrition, vol. 123, no. 10, pp. 1081-1093, 2020.

[39] H. Ketola, "Choline metabolism and nutritional requirement of lake trout (Salvelinus namaycush)," Journal of Animal Science, vol. 43, no. 2, pp. 474-477, 1976.

[40] G. L. Rumsey, "Choline-betaine requirements of rainbow trout (Oncorhynchus mykiss)," Aquaculture, vol. 95, no. 1-2, pp. 107-116, 1991.

[41] H. A. Poston, "Effect of body size on growth, survival, and chemical composition of Atlantic salmon fed soy lecithin and choline," The Progressive Fish-Culturist, vol. 52, no. 4, pp. 226-230, 1990.

[42] C. Oikawa and B. March, "Communications: a method for assessment of the efficacy of feed attractants for fish," The Progressive Fish-Culturist, vol. 59, no. 3, pp. 213-217, 1997.

[43] A. V. Suresh, K. P. Kumaraguru Vasagam, and S. Nates, "Attractability and palatability of protein ingredients of aquatic and terrestrial animal origin, and their practical value for blue shrimp, Litopenaeus stylirostris fed diets formulated with high levels of poultry byproduct meal," Aquaculture, vol. 319, no. 1-2, pp. 132-140, 2011.

[44] C. L. Cahu, E. Gisbert, L. A. Villeneuve et al., "Influence of dietary phospholipids on early ontogenesis of fish," Aquaculture Research, vol. 40, no. 9, pp. 989-999, 2009.

[45] J. F. Taylor, L. Martinez-Rubio, J. del Pozo et al., "Influence of dietary phospholipid on early development and performance of Atlantic salmon (Salmo salar)," Aquaculture, vol. 448, pp. 262-272, 2015.

[46] M. B. Betancor, S. Nordrum, E. Atalah et al., "Potential of three new krill products for seabream larval production," Aquaculture Research, vol. 43, no. 3, pp. 395-406, 2012.

[47] N. F. Haard, "Control of chemical composition and food quality attributes of cultured fish," Food Research International, vol. 25, no. 4, pp. 289-307, 1992.

[48] T. Mørkøre and K.-A. Rørvik, "Seasonal variations in growth, feed utilisation and product quality of farmed Atlantic salmon (Salmo salar) transferred to seawater as $0+$ smolts or 1+ smolts," Aquaculture, vol. 199, no. 1, pp. 145-157, 2001.

[49] J. S. Torgersen, E. O. Koppang, L. H. Stien, A. Kohler, M. E. Pedersen, and T. Mørkøre, "Soft texture of Atlantic salmon fillets is associated with glycogen accumulation," PLoS One, vol. 9, no. 1, p. e85551, 2014.

[50] J. O. Veland and O. J. Torrissen, "The texture of Atlantic salmon (Salmo salar) muscle as measured instrumentally using TPA and Warner-Brazler shear test," Journal of the Science of Food and Agriculture, vol. 79, no. 12, pp. 1737-1746, 1999.

[51] A. Koteng, Markedsundersokelse Norsk Laks (Market Investigation Norwegian Salmon), Prosjekt God Fisk, Bergen, Norway, 1992.

[52] M. Espe, K. Ruohonen, M. Bjørnevik, L. Frøyland, R. Nortvedt, and A. Kiessling, "Interactions between ice storage time, collagen composition, gaping and textural properties in farmed salmon muscle harvested at different times of the year," Aquaculture, vol. 240, no. 1-4, pp. 489-504, 2004.
[53] T. Mørkøre, H. Moreno, J. Borderías et al., "Dietary inclusion of Antarctic krill meal during the finishing feed period improves health and fillet quality of Atlantic salmon (Salmo salar L.)," British Journal of Nutrition, vol. 124, no. 4, pp. 140, 2020.

[54] L. Tskhovrebova and J. Trinick, "Making muscle elastic: the structural basis of myomesin stretching," PLoS Biology, vol. 10, no. 2, p. e1001264, 2012.

[55] T. Maoka, M. Katsuyama, N. Kaneko, and T. Matsuno, "Stereochemical investigation of carotenoids in the antarctic krill Euphausia superba," Bulletin of the Japanese Society of Scientific Fisheries, vol. 51, no. 10, pp. 1671-1673, 1985.

[56] W. Aoi, T. Maoka, R. Abe, M. Fujishita, and K. Tominaga, "Comparison of the effect of non-esterified and esterified astaxanthins on endurance performance in mice," Journal of Clinical Biochemistry and Nutrition, vol. 62, no. 2, pp. 161-166, 2018.

[57] P. Foss, T. Storebakken, K. Schiedt, S. Liaaen-Jensen, E. Austreng, and K. Streiff, "Carotenoids in diets for salmonids: I. Pigmentation of rainbow trout with the individual optical isomers of astaxanthin in comparison with canthaxanthin," Aquaculture, vol. 41, no. 3, pp. 213-226, 1984.

[58] T. Storebakken, P. Foss, E. Austreng, and S. Liaaen-Jensen, "Carotenoids in diets for salmonids: II. Epimerization studies with astaxanthin in Atlantic salmon," Aquaculture, vol. 44, no. 4, pp. 259-269, 1985.

[59] T. M. Scott, B. A. Rasco, and R. W. Hardy, "Stability of krill meal, astaxanthin, and canthaxanthin color in cultured rainbow trout (Oncorthynchus mykiss) fillets during frozen storage and cooking," Journal of Aquatic Food Product Technology, vol. 3, no. 4, pp. 53-64, 1995.

[60] S. A. Turujman, W. G. Wamer, R. R. Wei, and R. H. Albert, "Rapid liquid chromatographic method to distinguish wild salmon from aquacultured salmon fed synthetic astaxanthin," Journal of AOAC International, vol. 80, no. 3, pp. 622-632, 1997.

[61] Additives, E. P. O. and Feed, P. O. S. U. I. A, "Scientific opinion on the safety and efficacy of synthetic astaxanthin as feed additive for salmon and trout, other fish, ornamental fish, crustaceans and ornamental birds," EFSA Journal, vol. 12, no. 6, p. 3724, 2014.

[62] B. P. Lim, A. Nagao, J. Terao, K. Tanaka, T. Suzuki, and K. Takama, "Antioxidant activity of xanthophylls on peroxyl radical-mediated phospholipid peroxidation," Biochimica et Biophysica Acta (BBA)-Lipids and Lipid Metabolism, vol. 1126, no. 2, pp. 178-184, 1992.

[63] W. Miki, "Biological functions and activities of animal carotenoids," Pure and Applied Chemistry, vol. 63, no. 1, pp. 141146, 1991.

[64] O. Hirayama, K. Nakamura, S. Hamada, and Y. Kobayasi, "Singlet oxygen quenching ability of naturally occurring carotenoids," Lipids, vol. 29, no. 2, pp. 149-150, 1994.

[65] N. Shimidzu, M. Goto, and W. Miki, "Carotenoids as singlet oxygen quenchers in marine organisms," Fisheries Science, vol. 62, no. 1, pp. 134-137, 1996.

[66] R. G. Fassett and J. S. Coombes, "Astaxanthin: a potential therapeutic agent in cardiovascular disease," Marine Drugs, vol. 9, no. 3, pp. 447-465, 2011.

[67] A. Guillou, G. Choubert, T. Storebakken, J. De la Noüet, and S. Kaushik, "Bioconversion pathway of astaxanthin into retinol2 in mature rainbow trout (Salmo gairdneri Rich.)," 
Comparative Biochemistry and Physiology Part B: Comparative Biochemistry, vol. 94, no. 3, pp. 481-485, 1989.

[68] M. Ahmadi, A. Bazyar, S. Safi, T. Ytrestøyl, and B. Bjerkeng, "Effects of dietary astaxanthin supplementation on reproductive characteristics of rainbow trout (Oncorhynchus mykiss)," Journal of Applied Ichthyology, vol. 22, no. 5, pp. 388-394, 2006.

[69] J. Sawanboonchun, W. J. Roy, D. A. Robertson, and J. G. Bell, "The impact of dietary supplementation with astaxanthin on egg quality in Atlantic cod broodstock (Gadus morhua, L.)," Aquaculture, vol. 283, no. 1-4, pp. 97-101, 2008.

[70] V. Verakunpiriya, K. Mushiake, K. Kawano, and T. Watanabe, "Supplemental effect of astaxanthin in broodstock diets on the quality of yellowtail eggs," Fisheries Science, vol. 63, no. 5, pp. 816-823, 1997.

[71] R. Christiansen and O. J. Torrissen, "Effects of dietary astaxanthin supplementation on fertilization and egg survival in Atlantic salmon (Salmo salar L.)," Aquaculture, vol. 153, no. 1-2, pp. 51-62, 1997.

[72] R. Christiansen and O. Torrissen, "Growth and survival of Atlantic salmon, Salmo salar L. fed different dietary levels of astaxanthin. Juveniles," Aquaculture Nutrition, vol. 2, no. 1, pp. 55-62, 1996.

[73] J. G. Bell, R. J. Henderson, D. R. Tocher et al., "Substituting fish oil with crude palm oil in the diet of Atlantic salmon (Salmo salar) affects muscle fatty acid composition and hepatic fatty acid metabolism," The Journal of Nutrition, vol. 132, no. 2, pp. 222-230, 2002.

[74] B. Torstensen, Ø. Lie, and K. Hamre, “A factorial experimental design for investigation of effects of dietary lipid content and pro-and antioxidants on lipid composition in Atlantic salmon (Salmo salar) tissues and lipoproteins," Aquaculture Nutrition, vol. 7, no. 4, pp. 265-276, 2001.

[75] M. B. Betancor, A. Ortega, F. de la Gándara, D. R. Tocher, and G. Mourente, "Performance, feed utilization, and hepatic metabolic response of weaned juvenile Atlantic bluefin tuna (Thunnus thynnus L.): effects of dietary lipid level and source," Fish Physiology and Biochemistry, vol. 45, no. 2, pp. 697-718, 2019.

[76] A. G. J. Tacon, "Nutritional fish pathology," in Morphological signs of nutrient deficiency and toxicity in farmed fish, no. 330p. 75, FAO Fish Technical Paper, 1992.

[77] A. Nicolas, R. Aubert, N. Bellili-Munoz et al., "T-cadherin gene variants are associated with type 2 diabetes and the fatty liver index in the French population," Diabetes \& Metabolism, vol. 43, no. 1, pp. 33-39, 2017.

[78] R. Waagb $\varnothing$, M. Berntssen, T. Danielsen et al., "Feeding Atlantic salmon diets with plant ingredients during the seawater phase-a full-scale net production of marine protein with focus on biological performance, welfare, product quality and safety," Aquaculture Nutrition, vol. 19, no. 4, pp. 598618, 2013.

[79] H. Bjørgen, E. O. Koppang, G. Gunnes et al., "Ectopic epithelial cell clusters in salmonid intestine are associated with inflammation," Journal of Fish Diseases, vol. 41, no. 7, pp. 1031-1040, 2018.

[80] O. B. Dale, B. Tørud, A. Kvellestad, H. S. Koppang, and E. O. Koppang, "From chronic feed-induced intestinal inflammation to adenocarcinoma with metastases in salmonid fish," Cancer Research, vol. 69, no. 10, pp. 4355-4362, 2009.

[81] J. Fu, M. J. Bonder, M. C. Cenit et al., "The gut microbiome contributes to a substantial proportion of the variation in blood lipids," Circulation Research, vol. 117, no. 9, pp. 817$824,2015$.

[82] A. Koh, F. De Vadder, P. Kovatcheva-Datchary, and F. Bäckhed, "From dietary fiber to host physiology: shortchain fatty acids as key bacterial metabolites," Cell, vol. 165, no. 6, pp. 1332-1345, 2016.

[83] A. Nishida, R. Inoue, O. Inatomi, S. Bamba, Y. Naito, and A. Andoh, "Gut microbiota in the pathogenesis of inflammatory bowel disease," Clinical Journal of Gastroenterology, vol. 11, no. 1, pp. 1-10, 2018.

[84] D. Sterlin, J. Fadlallah, E. Slack, and G. Gorochov, "The antibody/microbiota interface in health and disease," Mucosal Immunology, vol. 13, no. 1, pp. 3-11, 2020.

[85] K. Gajardo, A. Rodiles, T. M. Kortner et al., "A highresolution map of the gut microbiota in Atlantic salmon (Salmo salar): A basis for comparative gut microbial research," Scientific Reports, vol. 6, no. 1, 2016.

[86] P. P. Lyons, J. F. Turnbull, K. A. Dawson, and M. Crumlish, "Exploring the microbial diversity of the distal intestinal lumen and mucosa of farmed rainbow trout Oncorhynchus mykiss (W albaum) using next generation sequencing (NGS)," Aquaculture Research, vol. 48, no. 1, pp. 77-91, 2017.

[87] A. R. Desai, M. G. Links, S. A. Collins et al., "Effects of plantbased diets on the distal gut microbiome of rainbow trout (Oncorhynchus mykiss)," Aquaculture, vol. 350, pp. 134142, 2012.

[88] Y. Jin, I. L. Angell, S. R. Sandve, L. G. Snipen, Y. Olsen, and K. Rudi, "Atlantic salmon raised with diets low in longchain polyunsaturated n-3 fatty acids in freshwater have a Mycoplasma-dominated gut microbiota at sea," Aquaculture Environment Interactions, vol. 11, pp. 31-39, 2019.

[89] M. S. Llewellyn, P. McGinnity, M. Dionne et al., "The biogeography of the Atlantic salmon (Salmo salar) gut microbiome," The ISME Journal, vol. 10, no. 5, pp. 1280-1284, 2016.

[90] C. E. Dehler, C. J. Secombes, and S. A. Martin, "Environmental and physiological factors shape the gut microbiota of Atlantic salmon parr (Salmo salar L.)," Aquaculture, vol. 467, pp. 149-157, 2017.

[91] S. Gupta, J. Fernandes, and V. Kiron, “Antibiotic-induced perturbations are manifested in the dominant intestinal bacterial phyla of Atlantic salmon," Microorganisms, vol. 7, no. 8, p. 233, 2019.

[92] F. He, J. Zhai, L. Zhang et al., "Variations in gut microbiota and fecal metabolic phenotype associated with Fenbendazole and Ivermectin tablets by $16 \mathrm{~S}$ rRNA gene sequencing and LC/MS-based metabolomics in Amur tiger," Biochemical and Biophysical Research Communications, vol. 499, no. 3, pp. 447-453, 2018.

[93] C. D. Nguyen, G. Amoroso, T. Ventura, J. J. Minich, and A. Elizur, "Atlantic salmon (Salmo salar L., 1758) gut microbiota profile correlates with flesh pigmentation: cause or effect?," Marine Biotechnology, vol. 22, pp. 786-804, 2020.

[94] E. Ring $\varnothing$, S. Sperstad, R. Myklebust et al., "The effect of dietary krill supplementation on epithelium-associated bacteria in the hindgut of Atlantic salmon (Salmo salar L.): a microbial and electron microscopical study," Aquaculture Research, vol. 37, no. 16, pp. 1644-1653, 2006.

[95] D. Osei-Hyiaman, M. DePetrillo, P. Pacher et al., "Endocannabinoid activation at hepatic CB 1 receptors stimulates fatty acid synthesis and contributes to diet-induced obesity," The 
Journal of Clinical Investigation, vol. 115, no. 5, pp. 12981305, 2005.

[96] M. Sakai, "Current research status of fish immunostimulants," Aquaculture, vol. 172, no. 1-2, pp. 63-92, 1999.

[97] O. Le Pape, S. Bonhommeau, A.-E. Nieblas, and J.M. Fromentin, "Overfishing causes frequent fish population collapses but rare extinctions," Proceedings of the National Academy of Sciences, vol. 114, no. 31, pp. E6274-E6274, 2017.

[98] P. Y. Morimoto Kofuji, H. Hosokawa, and T. Masumoto, "Effects of dietary supplementation with feeding stimulants on yellowtail Seriola quinqueradiata (Temminck \& Schlegel; Carangidae) protein digestion at low water temperatures," Aquaculture Research, vol. 37, no. 4, pp. 366-373, 2006.

[99] R. A. Hites, J. A. Foran, D. O. Carpenter, M. C. Hamilton, B. A. Knuth, and S. J. Schwager, "Global assessment of organic contaminants in farmed salmon," Science, vol. 303, no. 5655, pp. 226-229, 2004.

[100] Authority, E. F. S, "Scientific statement on the health-based guidance values for dioxins and dioxin-like PCBs," EFSA Journal, vol. 13, no. 5, p. 4124, 2015.

[101] S. Gündoğdu, O. Eroldoğan, E. Evliyaoğlu, G. Turchini, and $\mathrm{X}$. Wu, "Fish out, plastic in: global pattern of plastics in commercial fishmeal," Aquaculture, vol. 534, p. 736316, 2021.

[102] T. Watanabe, T. Fujimura, M.-J. Lee, K. Fukusho, S. Satoh, and T. Takeuchi, "Effect of polar and nonpolar lipids from krill on quality of eggs of red seabream Pagrus major," Nippon Suisan Gakkaishi, vol. 57, no. 4, pp. 695-698, 1991, Retrieved from https://www.jstage.jst.go.jp/article/ suisan1932/57/4/57_4_695/_article.

[103] C. Mazorra, M. Bruce, J. Bell et al., "Dietary lipid enhancement of broodstock reproductive performance and egg and larval quality in Atlantic halibut (Hippoglossus hippoglossus)," Aquaculture, vol. 227, no. 1-4, pp. 21-33, 2003.

[104] J. Covello, S. Friend, S. Purcell et al., "Effects of orally administered immunostimulants on inflammatory gene expression and sea lice (Lepeophtheirus salmonis) burdens on Atlantic salmon (Salmo salar)," Aquaculture, vol. 366, pp. 9-16, 2012.

[105] S. Refstie, G. Baeverfjord, R. R. Seim, and O. Elvebø, "Effects of dietary yeast cell wall $\beta$-glucans and MOS on performance, gut health, and salmon lice resistance in Atlantic salmon (Salmo salar) fed sunflower and soybean meal," Aquaculture, vol. 305, no. 1-4, pp. 109-116, 2010.

[106] M. Moren, J. Suontama, G. -I. Hemre et al., "Element concentrations in meals from krill and amphipods,-Possible alternative protein sources in complete diets for farmed fish," Aquaculture, vol. 261, pp. 174-181, 2006.

[107] K. Kousoulaki, I. Rønnestad, R. Rathore et al., "Physiological responses of Atlantic salmon (Salmo salar L.) fed very low (3\%) fishmeal diets supplemented with feeding-modulating crystalline amino acid mixes as identified in krill hydrolysate," Aquaculture, vol. 486, pp. 184-196, 2018.

[108] M. Jalili, M. Gerdol, S. Greco et al., "Differential effects of dietary supplementation of krill meal, soybean meal, butyrate, and bactocell ${ }^{\circledR}$ on the gene expression of Atlantic Salmon Head Kidney," International Journal of Molecular Sciences, vol. 21 , no. 3 , p. $886,2020$. 